\title{
Characterization of clay deposit in the central region of Piauí for use in the ceramic industry
}

\section{Caracterização de jazida de argila na região central do Piauí para utilização em indústria cerâmica}

\author{
Kelson Silva de Almeida ${ }^{1}$, Roberto Arruda Lima Soares ${ }^{2}$, \\ José Milton Elias de Matos ${ }^{3}$
}

\footnotetext{
${ }^{1}$ Instituto Federal do Piauí - Campus Floriano, CEP: 64800-000, Floriano, PI, Brasil.

${ }^{2}$ Instituto Federal do Piauí - Campus Teresina Central, 64000-040, Teresina, PI, Brasil.

${ }^{3}$ Universidade Federal do Piauí, 64049-550, Teresina, PI, Brasil.

e-mail: eng.kelson@ifpi.edu.br, robertoarruda@ifpi.edu.br,jmematos@ufpi.edu.br
}

\begin{abstract}
The clay ceramics industry comprises materials used in construction (bricks, tiles, and expanded clay, among others), is of great importance for Brazilian economic development, and the industry is seeking new sources of raw material, mainly clay. The present work aims to characterize a clay deposit located in the central region of the state of Piauí, to make feasible its use as ceramic raw material, seeking to boost the clay ceramics industry. The chemical composition, the crystalline phases, and the plasticity of the clay were analyzed. Specimens were prepared by uniaxial pressing, dried in an oven at $110{ }^{\circ} \mathrm{C}$, and then heated to $900{ }^{\circ} \mathrm{C}, 1000{ }^{\circ} \mathrm{C}$, and $1100{ }^{\circ} \mathrm{C}$. Bending strength, apparent porosity, linear shrinkage, water absorption, and mineralogical, macrostructural, and microstructural analyses were determined. The results showed an improvement in the indices with the increase in the firing temperature and that the samples showed a reddish coloration due to the presence of iron, as well as quartz and kaolinite. Thus, the clay deposit has the potential to become raw material for the clay ceramics industry in the state of Piauí.
\end{abstract}

Keywords: clay, clay ceramics, deposits, technological properties.

\section{RESUMO}

A indústria da cerâmica de argila compreende materiais empregados na construção civil (tijolos, telhas, argila expandida, entre outros), é de grande importância para o desenvolvimento econômico brasileiro, e busca novas fontes de matéria-prima, principalmente argila. O presente trabalho tem por objetivo caracterizar uma jazida de argila localizada na região central do estado do Piaú, para viabilizar seu uso como matéria-prima cerâmica, buscando impulsionar a indústria de cerâmica de argila. A composição química, as fases cristalinas e a plasticidade da argila foram analisadas. As amostras foram preparadas por prensagem uniaxial, secas em estufa a $110^{\circ} \mathrm{C}$ e depois queimadas a $900{ }^{\circ} \mathrm{C}, 1000{ }^{\circ} \mathrm{C}$ e $1100{ }^{\circ} \mathrm{C}$. Determinou-se então a resistência à flexão, porosidade aparente, retração linear, absorção de água, além de análise mineralógica, macroestrutural e microestrutural. Os resultados mostraram uma melhora nos índices com o aumento da temperatura de queima e que as amostras apresentaram coloração avermelhada devido à presença de ferro, bem como quartzo e caulinita. Assim, o depósito de argila tem potencial para se transformar em matéria-prima para a indústria de cerâmica de argila no estado do Piauí.

Palavras-chave: argila, cerâmica de argila, jazida, propriedades tecnológicas.

\section{INTRODUCTION}

Ceramic material, among dozens of possible definitions, can be described as any product, composed of inorganic raw materials consisting of metallic and non-metallic elements, namely, natural or synthetic, who in a state of dust, is transformed by means of firing, into a solid object with useful applications [1]. Currently, ceramic materials have various applications, from adobe, kitchenware, and tiling to dental prostheses, electrical insulators, and coating of nuclear reactors, but the most visible use of ceramic materials is in the civil 
construction industry [2].

The civil construction sector is growing constantly; although this sector is responsible for relevant environmental demand, it also has a significant positive impact on society and the economy. In Brazil, this sector currently represents 5\% of national GDP and shows signs of growth [3].

Clay is the essential material from the point of view of technology for the manufacture of ceramic materials. Clay is heterogeneous and behaves differently according to its mineralogical and chemical composition, thus also affecting its chemical and physical properties, which are essential to the finished ceramic products [4].

The increased need of clay by the ceramics industry has caused environmental impacts, such as the need for increased volumes of raw material deposits and the search for new and better deposits; thus, sites that have the potential to become raw material producers for ceramic products are being studied increasingly [5].

As clay is a heterogeneous material, it is necessary to technologically characterize clay to verify the possibility of its use (clay ceramics, ceramics tiles, coating, and advanced ceramics, among others). Several studies have already been conducted with this important issue and are presented in sequence.

SILVA et al. [1] studied two types of clay in the southern region of the state of Amapá, aiming at the appropriate use as raw material for the ceramics industry. Specimens were prepared by uniaxial pressing and the water absorption, apparent porosity, linear shrinkage and flexural modulus of rupture, as well as mineralogical evolution after firing were determined. The results showed that one of the clays showed a better performance in the technological properties, having a red coloration and another presented clear color, with the potential to become refractory material.

BRITO et al. [2] characterized clays originating from deposits in the municipality of Cubati, PB, Brazil, aiming to establish their appropriate uses as raw materials for ceramics. The clays were subjected to physical, chemical, mineralogical, and thermal analyzes. The results proved that the clays were composed of smectite, quartz, and kaolinite. And three of them were suitable for use in ceramic tiles and one for clay ceramic.

MORENO et al. [6] analyzed clays used by a factory of ceramic blocks located in the center TatuíSorocaba - SP, Brazil. Physical, chemical, geochemical, mineralogical, and ceramic aspects were analyzed to assess their influence on the composition of the pastes, which were formulated and processed in the laboratory based on analysis of the consistency of clay-water mixtures. The results of the study showed that the method of analysis of curves of consistency of clay-water mixtures proved to be a quality control, for better use of materials and alternatives for adjusting the proportion of the components of a paste.

SANTOS et al. [7] characterized four different clays used in the production of ceramic tiles of the type BIIb in Sergipe State, Brazil. The clays were characterized by X-ray diffraction (XRD), X-ray fluorescence (FRX), thermogravimetric analysis (TG), differential thermal analysis (DTA), particle size distribution, Atterberg limits, and dilatometry. The results confirmed the correlation between the formation of the liquid phase and the reduction of porosity in the sintered ceramic bodies.

PEREIRA et al. [8] studied the smectite clays in the city of Sossego, Paraiba, Brazil. The samples were subjected to a physical, chemical and mineralogical characterization through the particle size distribution by laser diffraction, chemical composition by X-ray fluorescence, X-ray diffraction, differential thermal and thermogravimetric analyses. The results showed that the clays showed in their mineralogical composition smectite, kaolinite, feldspar, and quartz. In relation to the rheological properties, the results were promising for some samples for use in drilling fluids.

The papers suggest the need to know the clay as raw material to be able to indicate the true potential of the material. Thus, it is emphasized the importance of the study carried out in view of the need to characterize the mineralogy of clay deposits aiming at quality in the final product and sustainability of the ceramic sector. On this basis, the study aims to characterize a clay deposit located in the central region of the state of Piaui for use in the ceramic industry.

\section{MATERIAL AND METHODS}

The clay used in this study is from a deposit located in the central region of Piaú, more precisely, in the municipality of Oeiras (latitude: -7.0844417 and longitude: -42.1477047 ), in the territory of Vale do Canindé. The clay was dried in an oven at a temperature of $110{ }^{\circ} \mathrm{C}$ and then subjected to the grinding process performed by a hammer mill to reduce the particle size. Then, the material was passed through a ABNT 200 sieve $(0.075 \mathrm{~mm})$ for the characterization and analyses of technological properties.

The clay was characterized using the following techniques: granulometric analysis (AG; electrical sieve shaker, ABNT NBR 7181 [9]), chemical analysis by X-ray fluorescence, FRX (Epsilon-XL of PANa- 
lytical), thermogravimetric analysis, TG and differential thermal analysis, DTA (SDT-Q600 MARK TA Instruments - temperature range: room temperature to $1200{ }^{\circ} \mathrm{C}$; heating rate: $10{ }^{\circ} \mathrm{C} / \mathrm{min}$; atmosphere: air; flow of gas: $50 \mathrm{~mL} / \mathrm{min}$ ), XRD (XRD-6000 - SHIMADZU with $\mathrm{Cu}-\mathrm{K} \alpha$ radiation $(1.54060 \AA$ ) $, 25 \mathrm{kV}, 25 \mathrm{~mA}$, scan speed: $2^{\circ} / \mathrm{min}$, sampling pitch: $0.02^{\circ}$ and in the $2 \theta$ range of $0^{\circ}-80^{\circ}$ ), and plasticity index (liquid limit by ABNT NBR 6459 [10] and limit of plasticity by ABNT NBR 7180 [11]).

To prepare the specimens, the sample was mixed with a clay content of $7 \%$ moisture (moisture used by the industry) and pressed to $30 \mathrm{MPa}$. Fifty specimens were manufactured (size $12.0 \mathrm{~cm} \times 4.0 \mathrm{~cm} \times 2.0$ $\mathrm{cm}$ ). Then, the specimens were dried in an oven at $110^{\circ} \mathrm{C}$ for $24 \mathrm{~h}$ and subjected to heat treatment (firing) to $900{ }^{\circ} \mathrm{C}, 1000^{\circ} \mathrm{C}$, and $1100{ }^{\circ} \mathrm{C}$ at a heating rate of $5^{\circ} \mathrm{C} / \mathrm{min}$, with soaking time of $1 \mathrm{~h}$.

After firing, technological assays were performed on the specimens to determine the following properties: apparent porosity (PA), water absorption (AA), firing shrinkage, module of rupture, scanning electron microscopy (SEM performed on the sintered samples at $1000{ }^{\circ} \mathrm{C}$ ), and macrostructural analysis. Characterization by X-ray diffraction (XRD) of the samples fired after the tests were also performed.

\section{RESULTS AND DISCUSSION}

Table 1 presents the chemical composition of the clay sample, which is composed basically of $\mathrm{SiO}_{2}, \mathrm{Al}_{2} \mathrm{O}_{3}$, and $\mathrm{Fe}_{2} \mathrm{O}_{3}$, with a significant predominance of $\mathrm{SiO}_{2}$ that is associated with quartz and kaolinite in combination with $\mathrm{Al}_{2} \mathrm{O}_{3}$. These results are similar to those found in the literature [12-15]. The sample also presented $9.25 \%$ of $\mathrm{Fe}_{2} \mathrm{O}_{3}$, which is responsible for the red color of the ceramic piece, and $1.75 \%$ of $\mathrm{K}_{2} \mathrm{O}$, which is a melting component, essential for the manufacture of ceramics of low porosity, helping in the sintering of ceramics $[16,17]$. The loss on ignition is in the order of $11.83 \%$ and is mainly associated with chemical reactions (dihydroxylation of kaolinite) and the decomposition of organic matter present [18].

Table 1: Chemical composition of clay (\% by weight).

\begin{tabular}{cccccccccc}
\hline Sample & $\mathrm{SiO}_{2}$ & $\mathrm{Al}_{2} \mathrm{O}_{3}$ & $\mathrm{Fe}_{2} \mathrm{O}_{3}$ & $\mathrm{Na}_{2} \mathbf{O}$ & $\mathrm{K}_{2} \mathbf{O}$ & $\mathbf{S O}_{3}$ & $\mathrm{CaO}$ & Others & Lol $^{*}$ \\
\hline Clay & 48.14 & 26 & 9.25 & - & 1.75 & 0.51 & 0.27 & 2.25 & 11.83 \\
\hline
\end{tabular}

*LoI: Loss on ignition.

Table 2 and Figure 1 show the granulometric distribution of the clay sample. The classification of the International Society of Soil Science was used [19]. The sand fraction is represented by the percentage of the material having a dimension larger than $20 \mu \mathrm{m}(0.02 \mathrm{~mm})$, the silt fraction by the percentage between 2 and $20 \mu \mathrm{m}$, and the clay fraction by a grain size less than $2 \mu \mathrm{m}$. The clay fraction (less than $2 \mu \mathrm{m}$ ) corresponds to the fraction that confers the plasticity required to conform to the products. In the clay sample, this value is high and important in the resistance of the final material after firing $[1,12,13,20]$.

The sample has $52 \%$ of silt and $23 \%$ of clay, with average diameter of $15.8 \mu \mathrm{m}$. The quantity of fine material (clay) confers a greater packaging property to the sample, as the thinner materials fill the spaces left by the larger materials, and thus it is possible to obtain a denser and more resistant ceramic material due to the inhomogeneous distribution $[12,14]$.

Table 2: Granulometric composition in percentage of clay sample.

\begin{tabular}{ccccc}
\hline \multirow{2}{*}{ Sample } & Clay (\%) & Silt (\%) & Sand (\%) & Average Diameter \\
\cline { 2 - 5 } & $\mathrm{v} \% \leq 2 \mu \mathrm{m}$ & $2 \mu \mathrm{m}<\mathrm{v} \% \leq 20 \mu \mathrm{m}$ & $\mathrm{v} \% \leq 20 \mu \mathrm{m}$ & $\mu \mathrm{m}$ \\
\hline Clay & 23.50 & 52.40 & 24.10 & 15.80 \\
\hline
\end{tabular}




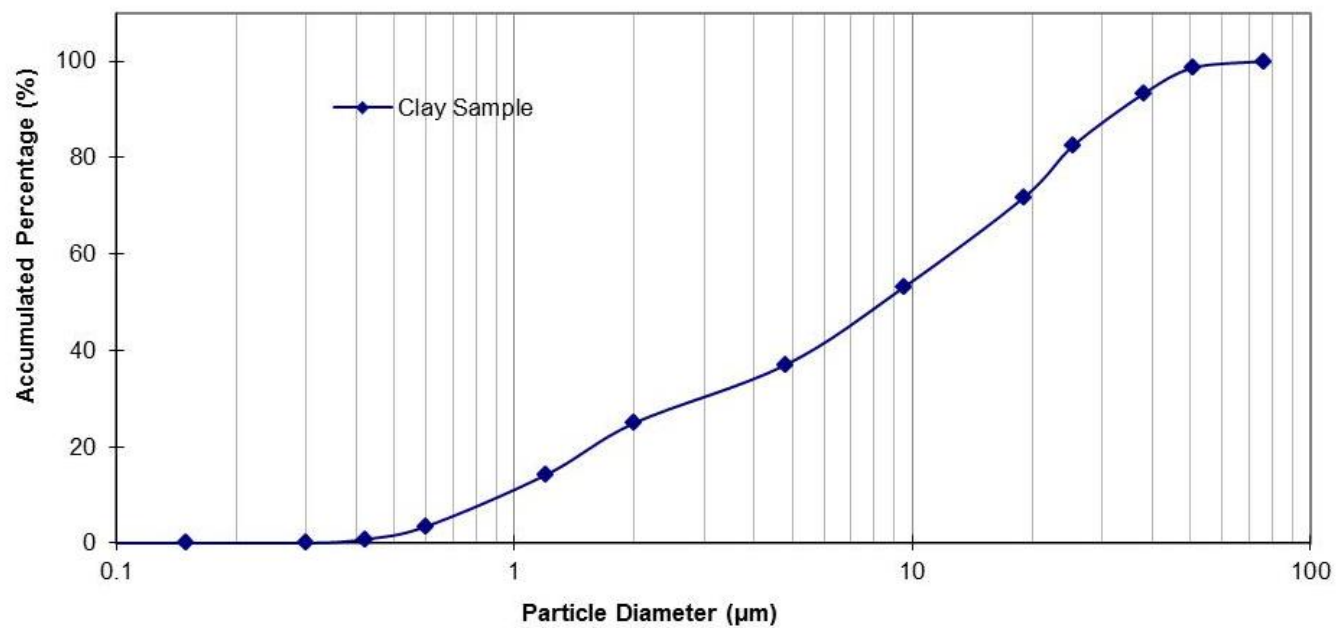

Figure 1: Granulometric distribution of the clay sample.

The plasticity index (PI) of the clay sample was also calculated and is shown in Table 3. The value obtained for the PI of the clay was $20.11 \%$. This value classifies it as a highly plastic material, because the value is above $15 \%$ (index of plasticity up to $7 \%$, poorly plastic; between $7 \%$ and $15 \%$, medium plastic; and greater than $15 \%$, highly plastic), as obtained in other studies $[6,21,22]$. The difference between the percentages obtained in the PI and the classification is closely related to the granulometric distribution that was shown previously, so a good amount of the clay fraction is present (in case of the presented sample) and it provides greater strength of the products [23]. It should also be considered that high plasticity can hinder the processing/conformation of the clay, so to reduce plasticity, it may be necessary to incorporate some clay with low plasticity or deplasticizing materials, as was done in some previous works [12, 13, 24-26].

Table 3: Plasticity index of the clay sample.

\begin{tabular}{cccc}
\hline \multirow{2}{*}{ SAMPLE } & LIQUID LIMIT (LL) & PLASTIC LIMIT (LP) & PLASTICITY INDEX (PI) \\
\cline { 2 - 4 } & $\%$ & $\%$ & $\%$ \\
\hline Clay & 42.56 & 22.45 & 20.11 \\
\hline
\end{tabular}

Figure 2 shows the Winkler diagram for the clay sample, in which appropriate regions for the processing of clay ceramics products are identified according to the granulometry of the material used [27]. The vertices of the diagram represent different sizes. From the diagram, it is possible to identify 4 main types of clay ceramics products, namely, A, suitable for high-quality products; B, for tiles; C, for hollow bricks; and D, for solid bricks [28]. According to the figure, a sample of clay of the deposit is suitable for manufacturing hollow bricks. 


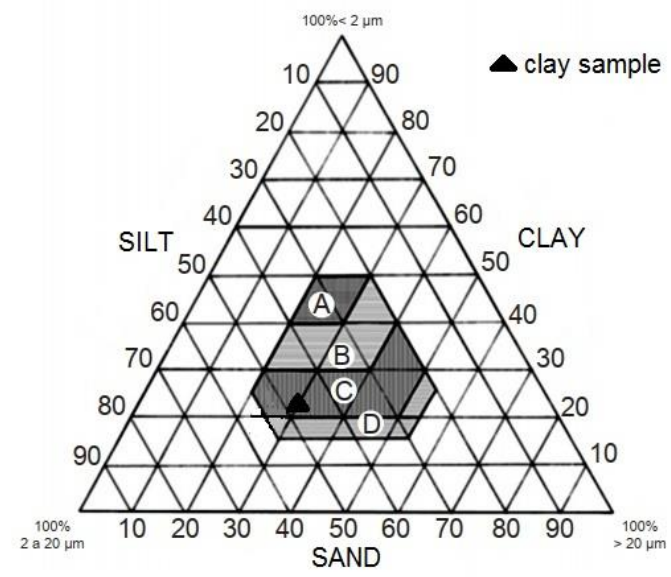

Figure 2: Winkler diagram for the clay sample.

Figures 3 and 4 present the results of the differential thermo analysis (DTA) and thermogravimetric analysis (TG) performed with the clay sample.

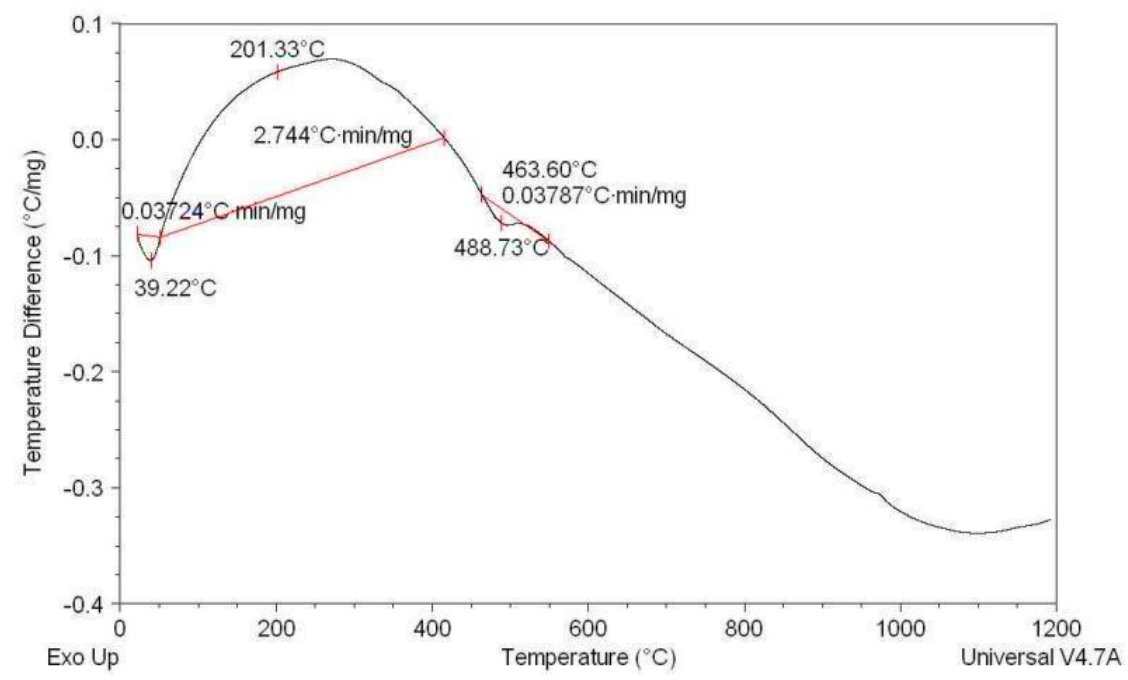

Figure 3: Differential thermo analysis (DTA) of clay.

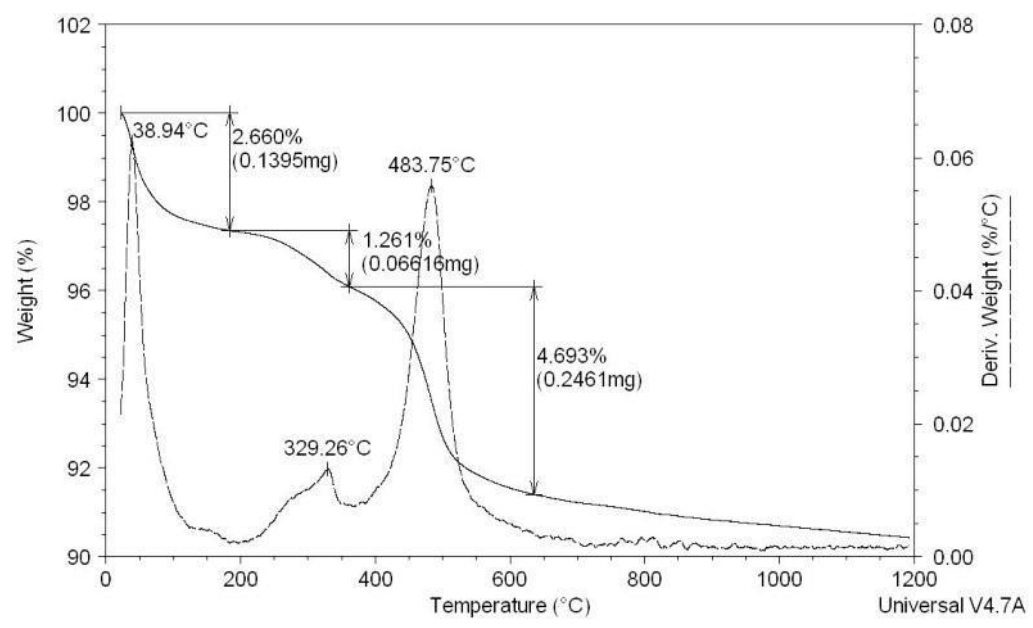

Figure 4: Thermogravimetric analysis (DTA) of clay. 
The DTA of the clay sample presented three main events: the first event was endothermic, with a maximum of $39.22{ }^{\circ} \mathrm{C}$; the second was exothermic at a temperature of $304.95{ }^{\circ} \mathrm{C}$; and the third event was endothermic, with a maximum of $488.73{ }^{\circ} \mathrm{C}$. In the TG of clay, it is possible to observe the occurrence of these three events, where the first event characterizes the release of free water around $39{ }^{\circ} \mathrm{C}(2.66 \%)$ and the second event shows the combustion of organic matter with a loss of mass of $1.26 \%$, with a maximum around $329.26{ }^{\circ} \mathrm{C}$, and the third event regarding the release of hydroxyls of the clay structure, with loss of mass of $4.69 \%$ at the temperature of $483.75^{\circ} \mathrm{C}$, presenting total loss of mass of approximately $8.61 \%$, corroborating with the values found in the loss on ignition presented previously, Table 1 . This result was expected for clays that have a high kaolinite content, as seen in the literature [29-31].

The X-ray diffractogram of the clay sample is shown in Figure 5, in which there are the diffraction peaks of crystalline phases relating to kaolinite (JCPDS 78-2110), quartz (JCPDS 46-1045) orthoclase (JCPDS 31-0966), and hematite (JCPDS 33-0664), corroborating the results of chemical composition by the presence of oxides: silicon, aluminum, potassium, and iron.

The quartz acts as the predominant mineral, and during firing acts as inert and non-plastic phase and may also be partially dissolved in the liquid phase formed. Kaolinite is responsible for the development of plasticity in the mixture with water and still features the refractory behavior of during firing. Kaolinite is the main mineral component of clay, responsible for the high mechanical resistance of ceramic products [32]. Whereas hematite is responsible for the reddish color of ceramic fired products, detected in the mineralogical analysis [18]. Orthoclase or potassic feldspar is the main raw material used as the flux and is of great benefit in ceramic pastes [33].

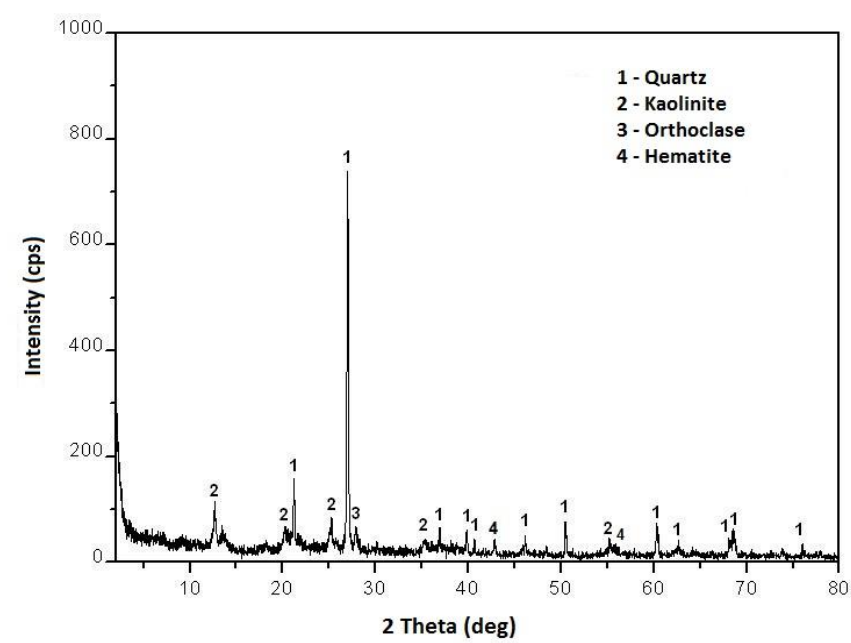

Figure 5: Diffractogram of the clay sample.

Figure 6 presents the macrostructural analysis needed to determine the possible visible cracks and fissures and to analyze the specimen's coloration after firing at $900{ }^{\circ} \mathrm{C}, 1000{ }^{\circ} \mathrm{C}$, and $1100{ }^{\circ} \mathrm{C}$. There is a red coloration of the specimens, which confirms the presence of iron in the chemical composition (iron oxide) and crystalline phases (hematite).

It may be noted that with the increase of temperature the red hue is more intense $\left(900{ }^{\circ} \mathrm{C}\right)$ reaching the tones of dark red $\left(1100^{\circ} \mathrm{C}\right)$. Over $1000^{\circ} \mathrm{C}$, the temperature in which the release of bivalent iron initiated, which by oxidation passes to trivalent iron responsible for the red color. Temperatures near $1100{ }^{\circ} \mathrm{C}$, in which overfiring initiates, the trivalent iron starts to reduce causing a dark reddish color from brown to black $[34,35]$.

It is also possible to see that the specimens do not show apparent fissures, agreeing with the granulometric analysis (packaging, and plasticizing) and the presence of oxides, being, therefore, a homogeneous sample. $[36,37]$. 


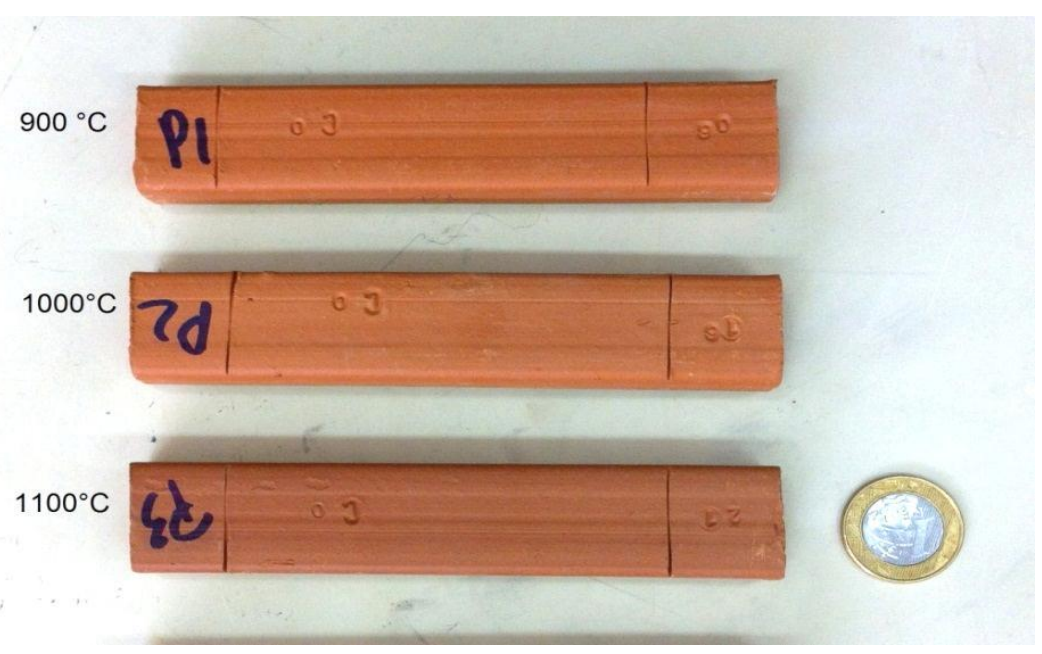

Figure 6: Samples of the specimens after firing.

The results of the technological tests of the clay sample at temperatures of $900{ }^{\circ} \mathrm{C}, 1000{ }^{\circ} \mathrm{C}$, and $1100{ }^{\circ} \mathrm{C}$ are presented in Figures $7-10$. Figure 7 presents the results of the linear shrinkage after firing. It can be noted that the linear shrinkage increases as the temperature increases, the behavior attributed to the closure of the porosity, which allows the densification of the samples accompanied by shrinkage, agreeing with the chemical composition; the presence of fluxing oxides that make this phenomenon possible.

The reference values for the linear shrinkage after firing are: less than 1.5\%; and acceptable: between $1.5 \%$ and $3 \%$ [38, 39]. According to the results, it is verified that the shrinkage after firing was within the pattern optimum for a sample of the studied deposits and temperatures [22].

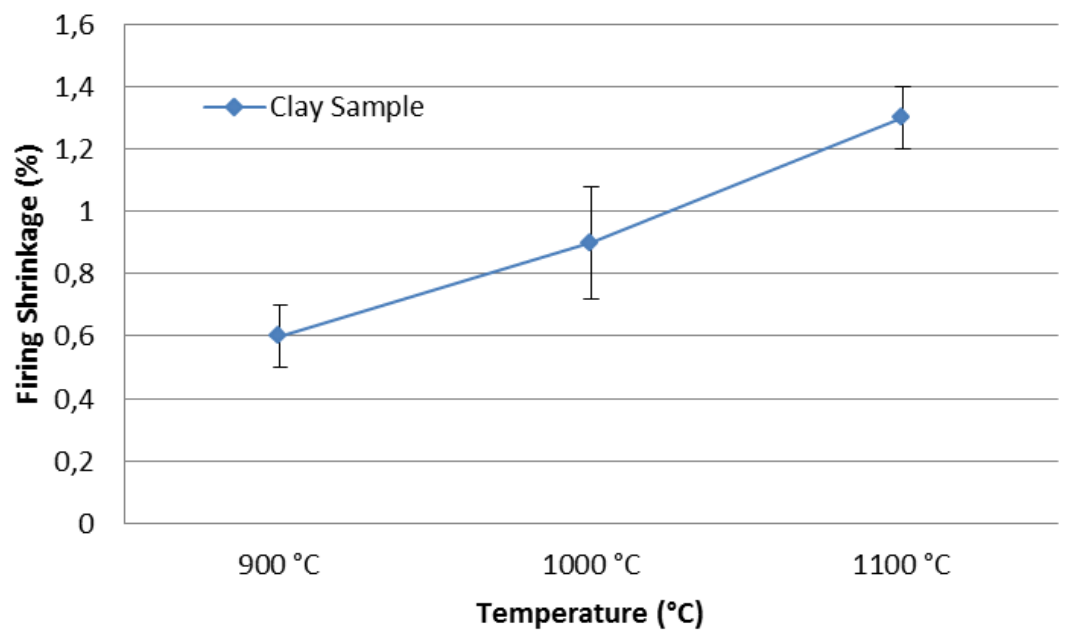

Figure 7: Linear shrinkage after firing of the clay sample.

Figure 8 shows the values obtained for the water absorption after the firing of clay sample in the temperature range. It may be noted that the content of water absorbed decreases as the temperature increases. The literature $[38,40,41]$ indicates that the water absorption index must be between $8 \%$ and $25 \%$ for bricks. Thus, the clay sample of the deposit is in accordance with the standard for all the firing temperatures and thus corroborates with the results already presented to shrinkage after firing and presence of fluxing oxides [42]. 


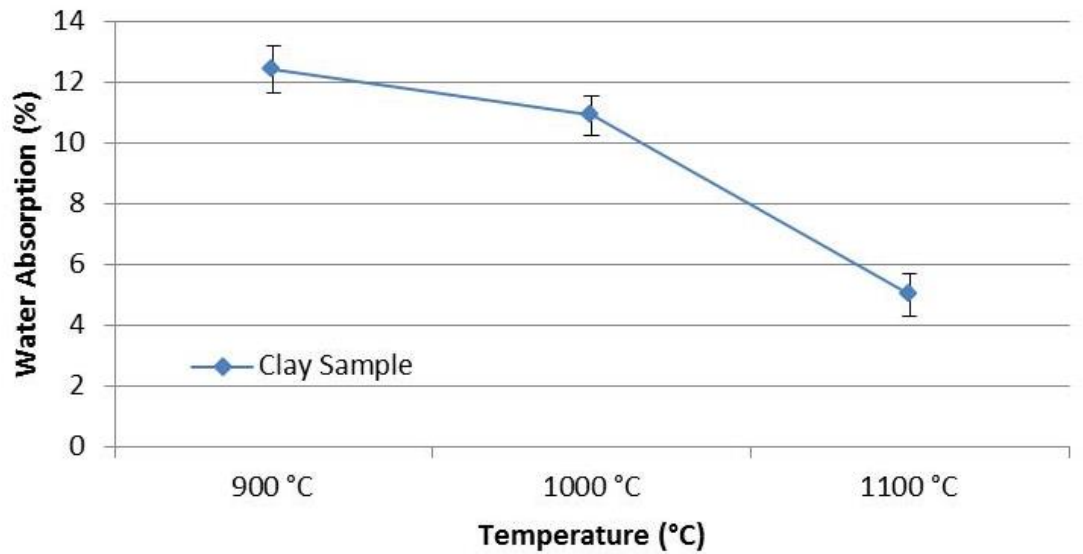

Figure 8: Water absorption for the specimens of clay.

Figure 9 presents the apparent porosity of the fired samples of clay to the proposed temperatures. The result shows a decrease in porosity with the increase in temperature, where at the temperature of $1100{ }^{\circ} \mathrm{C}$, the reduction was more significant.

This result is correlated to the water absorption, where the elimination of empty spaces was observed on the samples with the increase of temperature. $[1,7,16]$. During firing, the sintering of the standard composition promoted the formation of liquid phase of low viscosity at lower temperature. This liquid tends to fill the empty spaces between the refractory material of the specimen, reducing the porosity of the ceramic body.

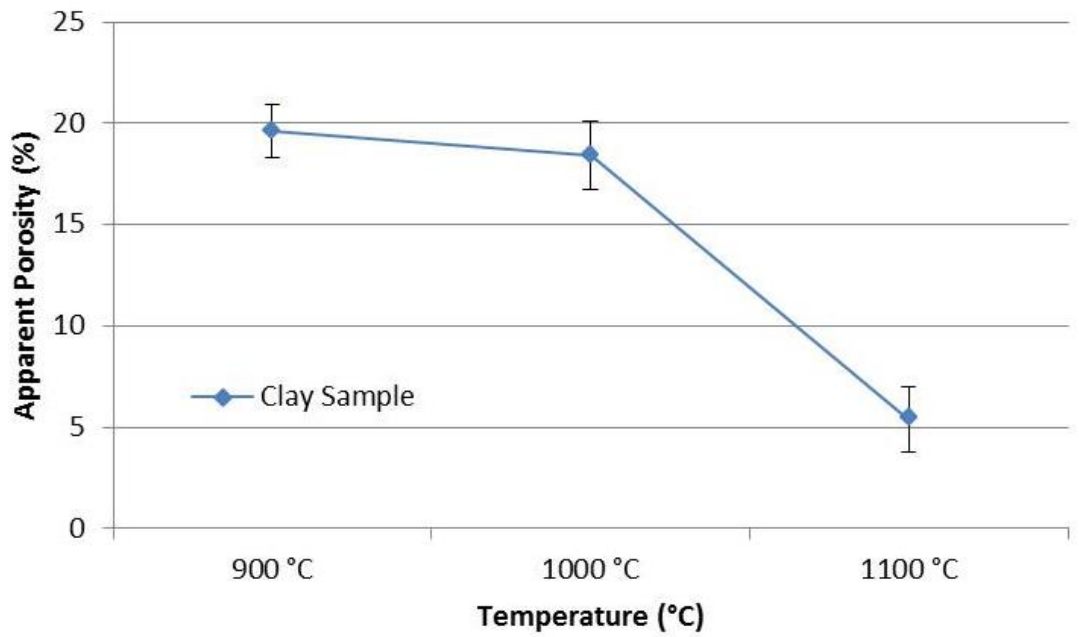

Figure 9: Apparent porosity for the specimens of clay.

Figure 10 shows the result for the bending strength after firing $\left(900{ }^{\circ} \mathrm{C}, 1000{ }^{\circ} \mathrm{C}\right.$, and $\left.1100{ }^{\circ} \mathrm{C}\right)$ of the clay specimens of the deposit. It is possible to notice that the bending strength increases as the temperature increases, i.e., increases the strength of the specimens.

According to the NBR 15270 [42] standard, the minimum bending strength at firing is 2.0 MPa $\left(20 \mathrm{kgf} / \mathrm{cm}^{2}\right)$ for wall sealing blocks, and thus, at all temperatures, the sample proved to be within the established standards. From the technological analyzes and results it is confirmed the viability and the possibility of use of the clay from the deposit as raw material in the clay ceramic industry, presenting acceptable results according to the legislation in force, as seen in the literature [1, 29, 43]. 


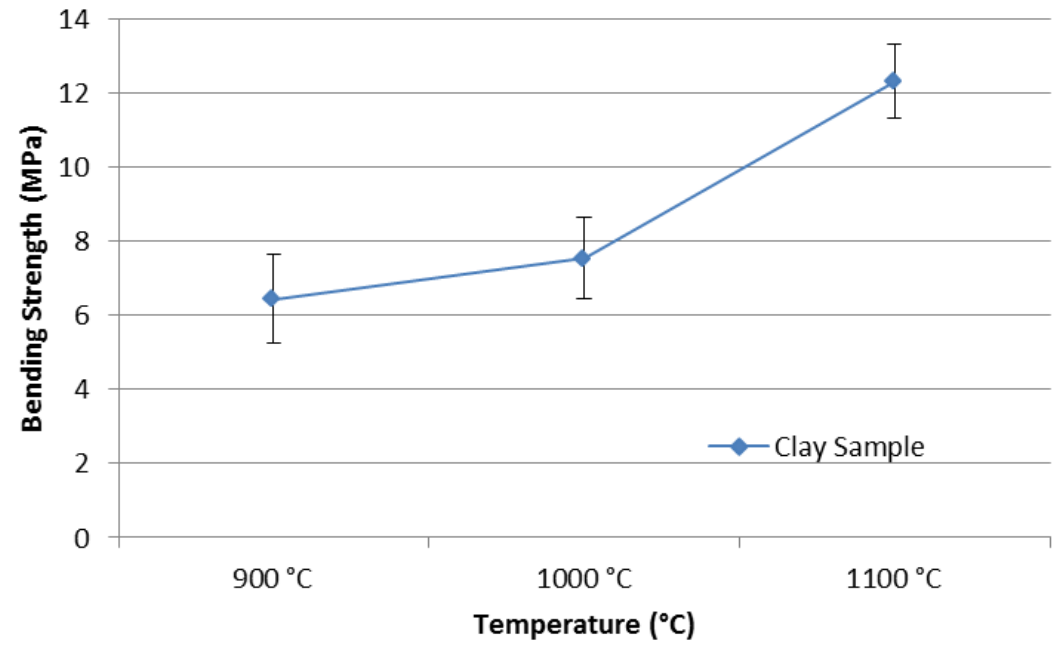

Figure 10: Bending strength for the specimens of clay.

Figure 11 shows the diffractogram of the fired clay sample at a temperature of $1000{ }^{\circ} \mathrm{C}$ (the other diffractogram presented the same characteristics). In accordance with the diffractogram, it is possible to verify that the peaks present the following crystalline phases: quartz (JCPDS 46-1045) and mullite (JCPDS 150776).

Quartz is the raw material in its natural state. Mullite is derived from the decomposition of metakaolinite, an amorphous phase formed from the elimination of the constituent water of kaolinite. The importance of mullite in traditional and advanced ceramics can be explained by the material properties: low density, high thermal stability, stability in harsh chemical environments, low thermal conductivity, good mechanical strength, and creep. The most important characteristic of mullite and mullite ceramics is their low thermal expansion, which explains their dimensional stability at high temperatures and excellent resistance to thermal shock [44-46].

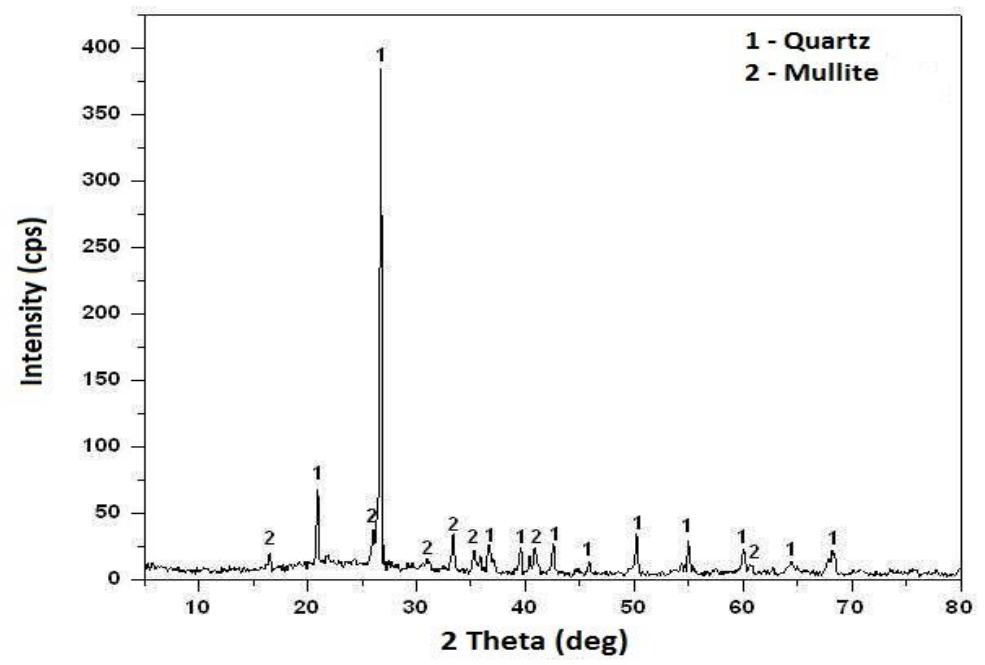

Figure 11: Diffractogram for the specimens of fired clay to $1000^{\circ} \mathrm{C}$.

Figures 12 and 13 show the micrographs obtained scanning electronic micrography (SEM) of the fired clay sample of at $1000{ }^{\circ} \mathrm{C}$, with a magnification of 500x and 5000x, respectively. 


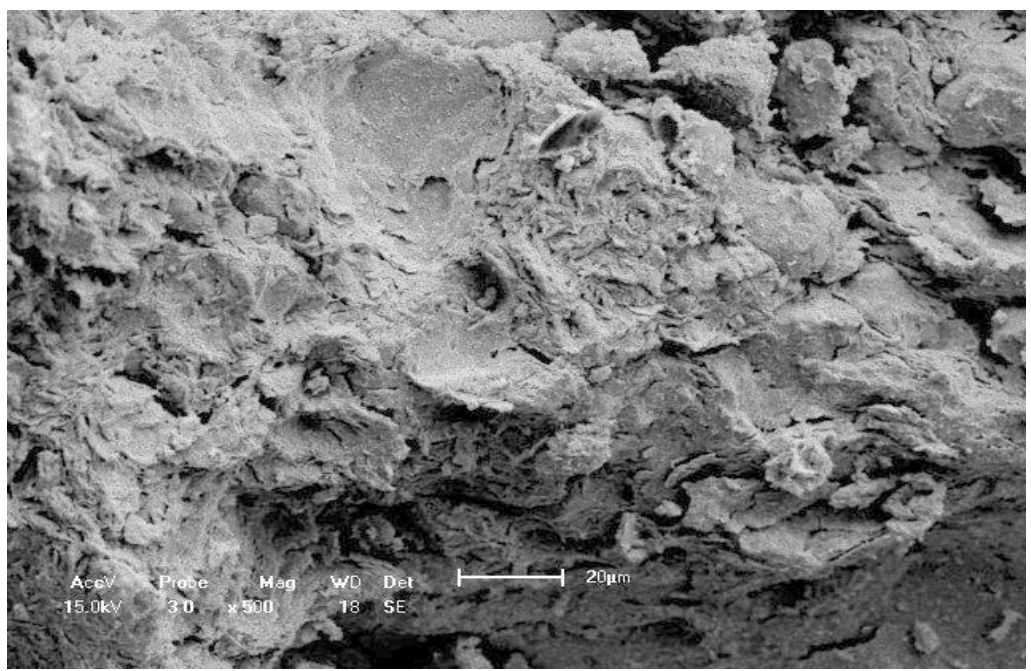

Figure 12: SEM micrographs of the composition $\mathrm{C} 0$ fired at $1000^{\circ} \mathrm{C}, 500 \mathrm{x}$.

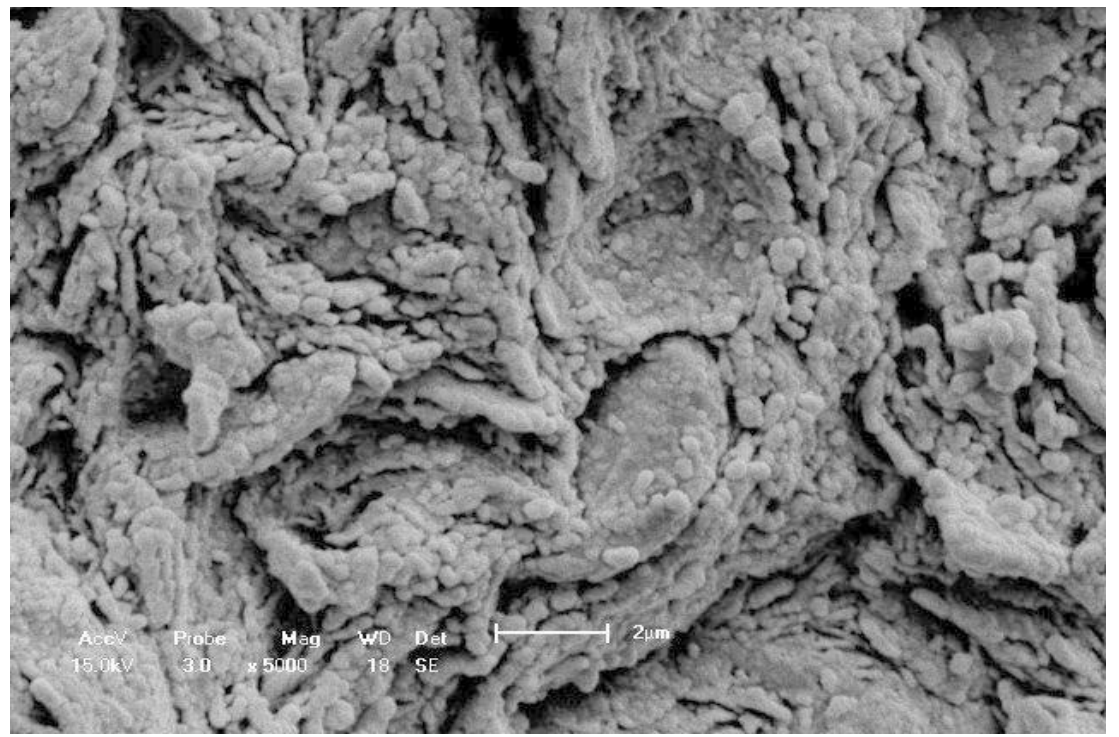

Figure 13: SEM micrographs of the composition $\mathrm{C} 0$ fired at $1000{ }^{\circ} \mathrm{C}, 5000 \mathrm{x}$.

The images show a more homogeneous microstructure, with high compaction and densification. This result corroborates with those obtained previously: the presence of mullite, fluxing oxides, high plasticity, low porosity, and high strength, among others. Several studies in the literature also presented these results [47-50].

\section{CONCLUSION}

The characterization of clay originating from the deposit located in the central region of the state of Piauí was performed. The chemical analysis showed the presence primarily of quartz, kaolinite, and fluxing oxides. The technological properties showed an improvement in the indices with the increase in the firing temperature (increased bending strength, decrease of porosity, and increasing linear shrinkage, among others).

Clay showed high plasticity and granulometric distribution quite heterogeneous, which explains the high level of densification presented in the micrographic images.

Thus, the clay deposit has the potential to be used as the raw material for the clay ceramics industry. 


\section{ACKNOWLEDGMENTS}

The authors thank the Federal Institute of Piauí (IFPI), the Federal University of Piauí (UFPI), the CTGASER in Rio Grande do Norte, and the company Cerâmica Vitória in Oeiras-PI.

\section{BIBLIOGRAPHY}

[1] SILVA, A. L., LUNA, C.B.B., CHAVES, A.C., et al. "Caracterização tecnológica de novos depósitos de argilas da região sul do Amapá visando aplicações na indústria Cerâmica", Matéria, v. 22, n.1, Maio 2017.

[2] BRITO, I. P., ALMEIDA, E. P., NEVES, G. A., et al. "Assessment of new clay deposits of Paraíba State for application as ceramic raw materials", Cerâmica, v. 61, pp. 391-398, Jul. 2015.

[3] INOCENTE, J. M., NANDI, V. S., ROSSO F., et al. "Estudo de Recuperação de Resíduos Vítreos na Formulação de Cerâmica Vermelha", Cerâmica Industrial, v. 23, n. 3, pp. 34-39, Jul. 2018.

[4] GOES, J. R, AZEVEDO, T. F., DUTRA, T. X. C., et al. "Evaluation of the potenciality of clays from the Calumbi and Riachuelo geological formation in Sergipe, Brazil, for application in ceramic tiles", Cerâmica, v. 60, pp. 211-217, 2014.

[5] MONTEIRO, S. N., VIEIRA, C. M. F., "Effect of oily waste addition to clay ceramic", Ceramics International, v. 31, n. 2, pp. 353-358, Set. 2005.

[6] MORENO, M. M. T., ROVERI, C., GODOY. L. H., et al. "Characterization of clays and ceramic mass compositions prepared on the basis of consistency curve analysis of clay-water mixtures", Cerâmica, v. 62, n.361, pp. 21-31, 2016.

[7] SANTOS, C. P., OLIVEIRA, H. A., OLIVEIRA, R. M. P. B., et al. "Caracterização de argilas calcárias utilizadas na produção de revestimentos cerâmicos no Estado de Sergipe - Brasil”, Cerâmica, v.62, n.362, pp.147-156, 2016.

[8] PEREIRA, I. D. S., SILVA, A., CARTAXO, J. M., et al. "Estudos de caracterização dos novos depósitos de argilas esmectíticas do município de Sossego, PB”, Cerâmica, v. 60, n.354, pp.223-230, 2014.

[9] ASSOCIAÇÃO BRASILEIRA DE NORMAS TÉCNICAS, NBR 7181: Solo - Análise granulométrica, Rio de Janeiro, ABNT, 1984.

[10] ASSOCIAÇÃO BRASILEIRA DE NORMAS TÉCNICAS, NBR 6459: Solo-Determinação do limite de liquidez, Rio de Janeiro, ABNT, 1984.

[11] ASSOCIAÇÃO BRASILEIRA DE NORMAS TÉCNICAS, NBR 7180: Solo - Determinação do limite de plasticidade, Rio de Janeiro, ABNT, 1984.

[12] SEGADÃES, M., CARVALHO, M. A., ACCHAR, W., "Using marble and granite rejects to enhance the processing of clay products", Applied Clay Science, v. 30, n. 1, pp. 42-52, 2005.

[13] SILVA, J. B., CINTHYA P., GONDIM, A., et al. "Incorporation of Coating Gypsum Residues in the Formulation of Red Ceramic Mass", Materials Science Forum, v. 636-637, pp.1397-1403, 2010.

[14] SANCHEZ, R., VIEIRA, C. M. F., SOARES, T. M., et al. "Incorporation of granite waste in red ceramics", Materials Science and Engineering, v. 373, n. 1-2, pp.115-121, 2004.

[15] SILVA, R. H. L., NEVES, G. A., FERREIRA, H. C., SANTANA, L. N. L., NÓBREGA, A. C. V., Menezes, R. R., "Uso de diopsídio em massas cerâmicas para grés sanitários". Cerâmica, v. 65, p. 1-12, 2019.

[16] CANDIDO, V. S., PINHEIRO, R. M., MONTEIRO, S. N., et al. "Desenvolvimento de adoquim cerâmico com argilas cauliníticas, chamote e argilito", Cerâmica, v. 59, n. 350, pp. 310-316, 2013.

[17] SOARES, R. A. L., NASCIMENTO, R. M., PASKOCIMAS, C. A., et al. "Avaliação da adição de dolomita em massa de cerâmica de revestimento de queima vermelha", Cerâmica, v. 60, n.356, pp.516-523, 2014.

[18] DUTRA, R., AQUINO, R., CAMPOS, L., et al., Adição de resíduo de lodo da indústria têxtil na produção de blocos cerâmicos de vedação, Revista Eletrônica De Materiais e Processos, v. 10, n. 1, pp. 29-35, 2015.

[19] BARNES, G., Soil Mechanics: Principles and Practice, 4 ed., Palgrave Macmillan, United Kingdom 2016.

[20] ARAÚJO, N. C., RAMOS, A. P., QUEIROZ, A. J. P., SANTOS, R. C., BURITI, J. S., "Propriedades mecânicas de tijolos fabricados com solo e água residuária de mandioca", Revista Verde de Agroecologia e Desenvolvimento Sustentável, v. 10, n. 2, pp. 213-217, 2015.

[21] OLIVEIRA, H. A., SANTOS, C. P., OLIVEIRA, R. M. P. B., et al. "Avaliação do potencial de argilas 
de Sergipe e Alagoas na produção de agregados para uso em concreto", Cerâmica, v. 63, n. 367, pp. 318-328, 2017.

[22] CAMPOS, L. F. A., MACEDO, R. S., KIYOHARA, P. K., et al. "Características de plasticidade de argilas para uso em cerâmica vermelha ou estrutural", Cerâmica, v. 45, n.295, pp.140-145, 1999.

[23] MAESTRELLI, S. C., ROVERI, C. D., NUNES, A. G. P., et al. "Estudo de caracterização de argilas não plásticas da região de Poços de Caldas, MG", Cerâmica, v. 59, n. 350, pp. 242-248, 2013.

[24] CONTRERAS, M., TEIXEIRA, S.R., SANTOS, G.T.A., et al. "Influence of the addition of phosphogypsum on some properties of ceramic tiles", Construction and Building Materials, v. 175, pp. 588-600, 2018.

[25] TORRES, P., FERNANDES, H. R., OLHERO, F., et al. "Incorporation of wastes from granite rock cutting and polishing industries to produce roof tiles", Journal of the European Ceramic Society, v. 29, n. 1, pp. 23-30, 2009.

[26] RAKHILA, Y. A., MESTARI, S. A., ELMCHAOURI, A., "Elaboration and characterization of new ceramic material from clay and phosphogypsum", Rasayan Journal of Chemistry, v. 11, n. 4, pp.1552-1563, 2018.

[27] VIEIRA, C. M. F., EMILIANO, J. V., "Incorporação de pó de rocha sedimentar em massas para telhas cerâmicas - parte 1: efeitos nas propriedades físicas e mecânicas", Cerâmica, v. 59, n. 351, pp. 389-394, 2013.

[28] CARREIRO, M. E. A., SANTOS, R. C., SILVA, V. J., et al. "Resíduo de quartzito - matéria-prima alternativa para uso em massas de cerâmica estrutural", Cerâmica, v. 62, n. 362, pp. 170-178, 2016.

[29] RAMOS, S. O., DANTAS, G. C. B., LIRA, H. L., et al. "Caracterização de argilas de novos jazimentos situados em Parelhas/RN, Brasil, visando aplicação na indústria cerâmica", Matéria, v. 24, n. 2, 2019.

[30] MEDEIROS, S. G., DUTRA, R. P. S., GRILO, J. P. F., et al. "Preparação de compósitos aluminamulita de baixo custo via sinterização reativa entre uma argila caulinítica da Paraíba e hidróxido de alumínio", $\mathrm{Ce}$ râmica, v. 62, n. 363, pp. 266-271, 2016.

[31] SANTOS, C. P., OLIVEIRA, H. A., OLIVEIRA, R. M. P. B., et al. "Caracterização de argilas calcárias utilizadas na produção de revestimentos cerâmicos no Estado de Sergipe - Brasil", Cerâmica, v. 62, pp. 147156, 2016.

[32] LIRA, H. L., NEVES, G. A., "Feldspatos: conceitos, estrutura cristalina, propriedades físicas, origem e ocorrências, aplicações, reservas e produção", Revista Eletrônica de Materiais e Processos, v. 8.3, pp. 110$117,2013$.

[33] ROVERI, C. D., ZANARDO, A., MORENO, M. M. T., "Variação da cor e propriedades cerâmicas com o aumento da temperatura de queima de uma argila proveniente da formação Corumbataí, região de Piracicaba, SP)", Cerâmica, v. 53, n. 328, pp. 436-441, 2007.

[34] TEIXEIRA, A. L., BORGES, D. C. M., SILVA, J. A., et al. "Influência dos tipos de matérias-primas e das condições de queima na cor do suporte cerâmico", Rev. Técnico Científica (IFSC), v. 3, n. 1, pp. 135-143, 2012.

[35] SANTOS, R. C., SILVA, T. R. DA, NEVES, G. A., et al. "Interação entre características de argilas e parâmetros de processamento sobre propriedades tecnológicas de corpos cerâmicos", Cerâmica, v. 63, n. 367, pp. 361-368, 2017.

[36] MACEDO, R. S.; MENEZES, R. R.; NEVES, G. A., et al. "Estudo de argilas usadas em cerâmica vermelha", Cerâmica, v. 54, n. 332, pp.411-417, 2008.

[37] DONDI, M., "Caracterização Tecnológica dos Materiais Argilosos: Métodos Experimentais e Interpretação dos Dados", Cerâmica Industrial, v. 11 n. 3, pp. 36-40, 2006.

[38] SILVA, A. L., LUNA, C. B. B., CHAVES, A. C., et al. "Avaliação de novos depósitos de argilas provenientes da região sul do Amapá visando aplicação na indústria cerâmica", Cerâmica, v. 64, n. 369, pp. 69-78, 2018.

[39] PILZ, S. E., PAVAN, R. C., RITTER, M. G., et al. "Verificação da Qualidade dos Blocos Cerâmicos Conforme NBR 15270 Comercializados em Santa Catarina", Revista de Engenharia Civil Imed, v. 2, n. 2, pp.19-26, 2015.

[40] SANTOS, P. S., Ciência e tecnologia de argilas, 2a Ed., Edgar blucher, São Paulo, 1992.

[41] MELO, R. A. A., SILVA, D. G., "Estudo da viabilidade do uso do fosfogesso como matéria-prima na produção de materiais cerâmicos", E-xacta, v. 6, n. 2, pp. 13-31, 2013.

[42] ASSOCIAÇÃO BRASILEIRA DE NORMAS TÉCNICAS, NBR 15270-1: Componentes cerâmicos 
Parte 1: Blocos cerâmicos para alvenaria de vedação - Terminologia e requisitos, Rio de Janeiro, ABNT, 2005.

[43] SANTOS, K. C. V., GONÇALVES, W. P., SILVA, V. J., et al. "Formação de Mulita a Partir de Composições de Caulim e Alumina com Diferentes Tamanhos de Partículas”, Revista Eletrônica de Materiais e Processos, v. 11, n. 3, pp. 136-142, 2016.

[44] FERREIRA, S. B., DOMINGUES, P. C., SOARES, S. M., et al. "Recycled Gypsum and Red Ceramic Waste Based Mortars”, International Journal of Engineering and Technology, v. 7, n. 3, pp. 209-214, 2015.

[45] ALEXANDRE, J., AZEVEDO, A. R. G., XAVIER, G. C., et al. "Influence of Weather Exposure on Dimensional Changes in Clay Ceramics Incorporated with Granite Residue", Materials Science Forum, v. 869, pp. 131-135, 2016.

[46] TAGUCHI, S. P., SANTOS, J. C., GOMES, T. M., et al. "Avaliação das propriedades tecnológicas de cerâmica vermelha incorporada com resíduo de rocha ornamental proveniente do tear de fio diamantado", Cerâmica, v. 60, n. 354, pp. 291-296, 2014.

[47] BABISK, M. P., VIDAL, F. W. H., RIBEIRO, W. S., et al. "Incorporação de resíduo de quartzitos em cerâmica vermelha", HOLOS, a. 28, v. 6, pp. 169-177, 2012.

[48] VIEIRA, M. F., PEÇANHA, L. A., MONTEIRO, S. N., "Reformulation of roofing tiles body with addition of granite waste from sawing operations", Journal of the European Ceramic Society, v. 24, n. 8, pp. 2349-2356, 2004.

[49] MOREIRA, J. M. S., FREIRE, M. N., HOLANDA, J. N. F., "Utilização de resíduo de serragem de granito proveniente do estado do Espírito Santo em cerâmica vermelha”, Cerâmica, v.49, n. 312, pp.262-267, 2003.

[50] CIPRIANO, P. B., REZENDE, R. T. O., FERRAZA, A. V., "Produção de cerâmica vermelha utilizando argila da mineração de gipsita e resíduo de gesso", Acta Brasiliensis, v. 3, n. 1, pp. 25-29, 2019.

\section{ORCID}

Kelson Silva de Almeida Roberto Arruda Lima Soares José Milton Elias de Matos https://orcid.org/0000-0001-5540-3091

https://orcid.org/0000-0003-1892-7499

https://orcid.org/0000-0003-3476-399X 